\section{Fungal stains on paper: \\ is what you see what you get?}

\section{Manchas de fungos em papel: o que se vê é o que se obtém?}

\author{
SÍLVIA OLIVEIRA \\ SEQUEIRA ${ }^{1,2 * \text { (1) }}$ \\ HUGO PAIVA DE \\ CARVALHO $^{3}$ (1) \\ NUNO MESQUITA 3 (1) \\ ANTÓNIO PORTUGAL ${ }^{3}$ (1) \\ MARIA FILOMENA \\ MACEDO $^{1,2}$ (1) \\ 1. Departamento de \\ Conservação e Restauro, \\ Universidade NOVA de Lisboa, \\ 2829-516 Caparica, Portugal \\ 2. VICARTE, Universidade \\ NOVA de Lisboa, 2829-516 \\ Caparica, Portugal \\ 3. Centre for Functional Ecology, \\ Department of Life Sciences, \\ University of Coimbra, 3000-456 \\ Coimbra, Portugal \\ *sos11865@campus.fct.unl.pt
}

\section{KEYWORDS}

Fungal stains

Mitigation of fungal biodeterioration on paper documents and artworks represents a challenge to conservators worldwide. Numerous lists of fungal species have been identified from paper collections, but are those species responsible for the respective biodeterioration phenomena or just environmental contaminants? The present work was aimed at obtaining an association between specific fungal stains and causative fungal species. 23 stains from three paper documents were sampled. Fungal structures observed in situ with optical and scanning electron microscopy were compared with the identification of isolates by molecular biology tools. Correlation between the observed fungal structures and the identified fungal isolates was achieved, varying from $13 \%$ to $64 \%$ of the samples within the three studied documents. Grey/black and dark brown stains were associated with Chaetomium globosum, C. murorum, Penicillium chrysogenum, P. commune, Myxotrichum deflexum and Stachybotrys chartarum. Eurotium rubrum was isolated from a foxing stain and Penicillium citrinum was identified on light orange stains.

\section{Resumo}

A mitigação da biodeterioração causada por fungos em obras de arte e documentos em papel representa um desafio para os conservadores em todo o mundo. Inúmeras listas de espécies fúngicas têm sido identificadas a partir de coleções em papel, mas serão estas espécies responsáveis pelos respetivos fenómenos de biodeterioração? O presente estudo teve como objetivo associar espécies de fungos específicas a manchas observadas em documentos e obras de arte em papel. Foram amostradas 23 manchas existentes em três obras em papel. A observação in situ das estruturas fúngicas, com recurso a microscópio ótico e microscópio eletrónico de varrimento, foi comparada com a identificação de isolados através de técnicas de biologia molecular. As manchas negras e de tom castanho-escuro foram associadas às espécies Chaetomium globosum, C. murorum, Penicillium chrysogenum, P. commune, Myxotrichum deflexum e Stachybotrys chartarum. A espécie Eurotium rubrum foi isolada de uma mancha de foxing e a espécie Penicillium citrinum foi identificada em manchas de tom laranja claro.
Paper conservation Identification of fungi SEM

DNA

\section{PALAVRAS-CHAVE}

Manchas de fungos Conservação de papel Identificação de fungos SEM

ADN 


\section{Introduction}

Biodeterioration caused by moulds is a major problem affecting paper-based collections in museums, archives and libraries all over the world [1]. Fungi have the ability to decompose paper materials, through the production of an array of deteriorating enzymes and metabolites, causing the loss of mechanical strength in paper. On an advanced stage of deterioration by fungi, paper acquires a felted consistency, with little or no mechanical resistance and its manipulation may result in losses of material and information. Besides chemical and physical damage, fungi often cause aesthetic alterations on paper through the production of coloured pigments, which interfere with the readability of the object and diminish their artistic and monetary value [2-3]. The chemical products excreted by the fungi will remain in the paper matrix and continue their deleterious effects, even after the fungi are inactivated [4]. Depending on the causative species is the treatment to be applied, e.g. different stains, created by different fungi, demand different conservation treatments [5]. However, one must acknowledge that determining the microorganisms responsible for paper biodeterioration can be a very complex process that has led to confusion and never-ending lists of possible culprits.

Fungi have been identified from paper sampling either by classic morphology identification or DNA sequencing (by culture dependent processes or direct DNA extraction) [6-11]. Different methods of analysis have their pros and cons. Conventional culturing methods highlight the viability of the fungal flora and are still the most currently used for fungal assessment. According to Sanmartín et al. [12], while cultivation methods generally recover less than $1 \%$ of the total amount of bacteria present in environmental samples, the recovery rate for fungi is estimated to be more than $70 \%$. Though timeconsuming and requiring a trained eye, morphologic characterization preceded by culture is widely available, allows for an easy isolation of single species and is relatively cheap. But it only provides a partial picture. Most of the knowledge on fungal flora is lost when using only morphologic characterization. Even though, the use of DNA based methods is still hampered by the high costs and needed technical expertise. Additionally, when extracting DNA directly from samples, the methods of separation may not be fully reliable on an actual scenario. Most studies that report fungal organisms dwelling on paper-based supports make use of the denaturing gradient gel electrophoresis (DGGE) method, involving the Sanger sequencing of the community DNA samples, with adequate designed primers, and rDNA library construction for clone profiles comparison [13-16]. DGGE has been applied to the typification of fungal communities in cultural heritage studies because of its advantage of directly profiling microbial populations present in specific artefact materials [13-14, 17]. However, in spite of being one of the most used culture-independent methods in microbial communities typification, it has a high cost per sequencing unit and few sequences are obtained with the clone libraries analysis, thus giving little information about the community structure [18-19]. Moreover, this technique does not provide any information on the activity/inactivity of a possible causative deteriogen species. Recently, next-generation sequencing (NGS) has also been used as a culture-independent method to assess microbial flora in cultural heritage materials [11, 20-22]. Even though this metagenomic analysis provides a fast and exhaustive identification of the present microorganisms, the operational taxonomic units (OTUs) are obtained with a maximum $97 \%$ similarity, which only allows for a reliable identification at the genera level.

Regardless of the method, the identification of a fungal genus or species sampled from a document does not necessarily mean it is the actual cause for the observed biodeterioration. In fact, what is identified may be contaminant species and not the actual colonization/degradation culprits [16]. A few recent studies are already examining microbial cells directly on biodeteriorated areas, to confirm the presence of colonizing microorganisms [15-16, 23], but there is still a general lack of knowledge of the association of particular types of biodeterioration with specific species.

The aim of the present work was therefore to correlate fungal stains observed on paper objects with the fungal species actually found colonizing those areas. To do so, the fungal species identified by morphologic and molecular biology methods were cross-checked with the fungal structures directly observed in the sampled stains, and the colour of the stain compared with colourant production by those species according to the literature. This is the first time such a systematic cross-validation is performed, to our knowledge.

\section{Materials and methods}

\section{Studied documents}

Two books and one print on paper, showing fungal stains, were selected (Figure 1). Document I (D1), a paperback wood pulp printed book dated from 1982, exhibited coloured stains mainly on the back cover and endleaves. Document 2 (D2), a quarter leather binding book dated from 1853, was composed of rag paper (endleaves) and printed wood pulp paper (text block). Coloured fungal stains were observed on the endleaves and foxing on the text block of D2. Document 3 (D3), a painted print on paper, was profusely stained, with severe loss of mechanical strength. In all three documents, the stains were located within or nearby areas delimited by tide lines, where direct contact with water took place.

\section{Microscopic examination of stains}

Stains with distinct appearances under the stereomicroscope (Leica MZ16) were selected and sampled using small squares $\left(2.25 \mathrm{~mm}^{2}\right)$ of adhesive tape (Scotch Magic), or scalpel and tweezers [24]. Collected samples were observed by 
optical microscopy (OM) (Zeiss Axioplan 2 imaging system) with lactofuchsin mounting fluid. When the results obtained by OM were non-conclusive, scanning electron microscopy (SEM) (field emission gun scanning electron microscope, JEOL 7001F) after Au/Pd sputter coating (Q150T ES, Quorum Technologies) was performed. Only the samples exhibiting fungal structures were selected for further analysis.

\section{Identication of fungal species}

Sterile cotton swabs were used to collect samples from the selected stains. After a brief shaking in sterile water, for propagule dispersion, the solution was inoculated in two Petri dishes, one with potato dextrose agar (PDA, Difco) and another with malt extract agar (MEA, Difco), followed by incubation at $28^{\circ} \mathrm{C}$. The dierent colonies were isolated into axenic cultures and incubated for subsequent morphologic and molecular identication. DNA was extracted from the colonies using the Extract-N-AMP (Sigma-Aldrich) kit, according to the manufacturer's instructions. After extraction, the ITS region was amplied by PCR, using ITS4 and ITS1F primers. For that purpose, PCR mixes were prepared with $12.5 \mu \mathrm{l}$ of Green Master MIX (NZYtech) with $\mathrm{MgCl}_{2}, 0.5 \mu$ l of each primer (10 mM), $10.5 \mu \mathrm{l}$ of ultra-pure water, and $1 \mu$ l of DNA extract, for a final reaction volume of $25 \mu \mathrm{l}$. PCR reactions were performed using an ABI GeneAmp PCR System 9700 (Applied Biosystems), with the following conditions: initial denaturation at $95^{\circ} \mathrm{C}$ for $2 \mathrm{~min}$, followed by 30 cycles of denaturation at $95^{\circ} \mathrm{C}$ for $1 \mathrm{~min}$, annealing at $53^{\circ} \mathrm{C}$ for $1 \mathrm{~min}$, and extension at $72^{\circ} \mathrm{C}$ for $1 \mathrm{~min}$, with a final extension at $72^{\circ} \mathrm{C}$ for $5 \mathrm{~min}$. Visual confirmation of the overall amplication of the ITS region was performed using agarose gel electrophoresis (1.2\%) stained with Greensafe Premium (NZYTech) and photographed in an image capture device (Bio Rad Gel Doc XR). Amplification products were sequenced using an ABI 3730 genetic analyser, with the Big Dye v.3 Terminator Cycle Sequencing Ready Reaction Kit (Applied Biosystems). Obtained sequences were analysed and ran in NCBI's BLAST (Basic Local Alignment Search Tool) database in order to assess the similarity with published sequences. For similarity values higher than 99\%, the molecular identication was considered a valid match, although thoroughly confirmed by morphological traits according to Watanabe [25] and Seifert et al. [26].

\section{Results and discussion}

Twenty-three stains with different appearances were sampled from the studied documents $\left(D_{1}=8 ; D_{2}=4 ; D_{3}=11\right)$. As presented in Table 1 , sampled stains of which observed fungal structures did not correspond to the identified fungal species, were classified as a negative correlation. On the other hand, when the observed fungal structures could have been produced by the identified fungal isolates we could not ascertain an unequivocal match since there are numerous
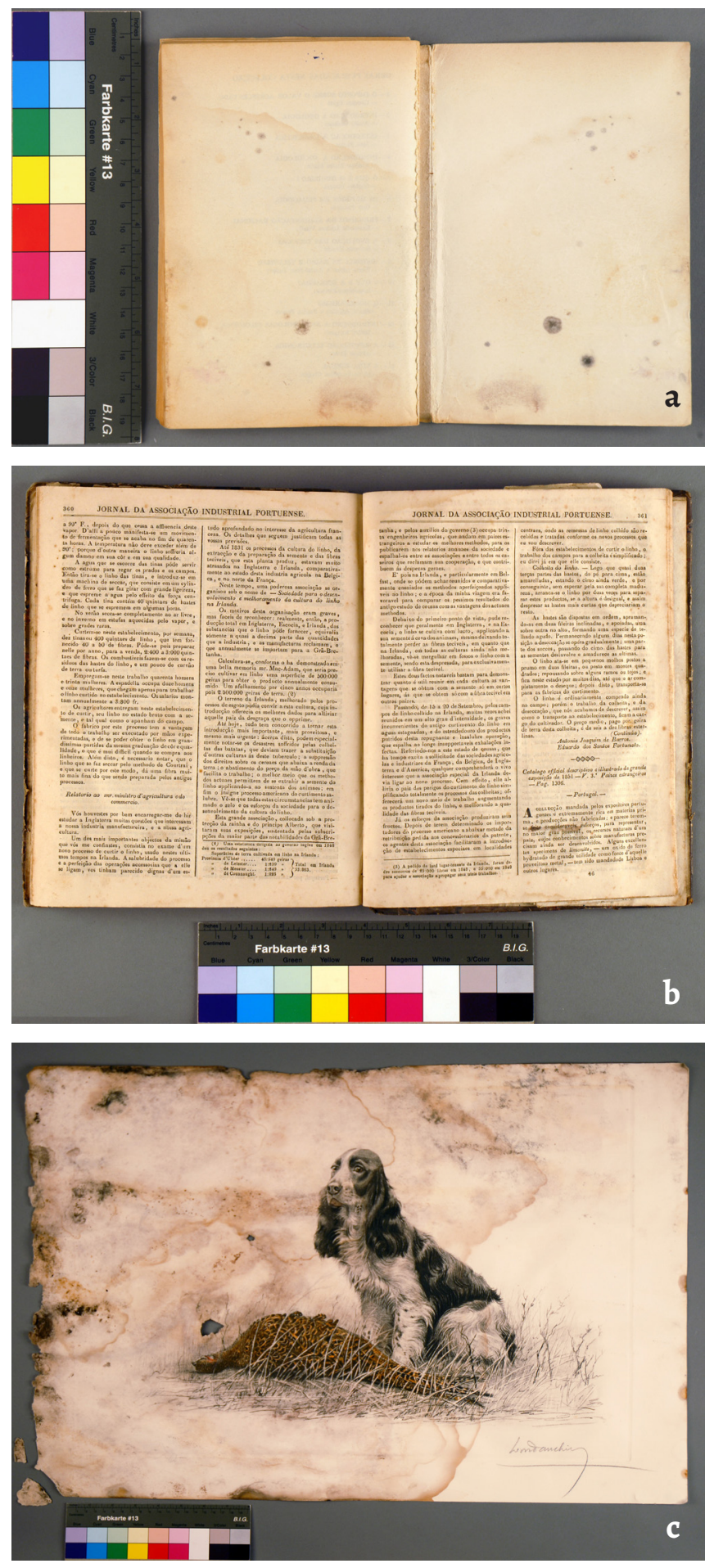

Figure 1. The three biodeteriorated documents used as case studies: a) Document 1; b) Document 2; c) Document 3.

species from each genus producing similar cells. In those cases, a possible correlation was assigned (Table 1 ).

The percentage of samples with retrievable isolates varied greatly within the three analysed documents, from $25 \%$ no D1 book to $82 \%$ on D3 print (Figure 2). Unlike documents D2 and D3, document Di had already been mechanically cleaned. This procedure, by removing the aerial reproductive structures, which are more resilient than vegetative structures, diminished the probability of collecting viable cells within 
the sampling swabs. On D3 print, conversely, the stains were profusely covered by aerial reproductive structures, increasing the probability of collecting the fungal cells belonging to the species responsible for the observed biodeterioration.

Within the two samples from Di yielding isolates (Table 1), no correspondence between the observed microbial structures in D1-B (Figure $3 \mathrm{a}$ and $3 \mathrm{~b}$ ) and the characteristic cells from the obtained isolates (P. citrinumand C. globosum) was achieved. In D1-H sampling point, though, black hairy ascomata were observed on top of the paper (Figure 3c) and brown, lemon-shaped cells $(9-10 \times 7-8.5 \mu \mathrm{m})$ observed within the paper fibres (Figure $3 \mathrm{~d}$ ), which are in accordance with the characteristic melanised perithecia and ascospores, respectively, of the identified Chaetomium globosum [27] (Table 1). C. globosum has ascospores instead of conidia, and ascospores have higher resistance to heat, pressure and chemicals [28], which may have contributed to the maintenance of this species viability within the sampled document. C. globosum has been frequently identified from paper objects $[3,11,29]$ and is able to colonize paper due to its amylolytic, cellulolytic, and proteolytic activities [30-31].

Document D2 showed Penicillium-like conidiophores on the light orange spots on stain D2-A, where P. citrinum was identified. Accordingly, this fungus is known to produce yellow-orange soluble colourants [32]. P. citrinum is commonly identified from paper collections [3, 6, 8, 33-35] and has shown to possess high amylolytic activity but low cellulolytic activity [36]. Even though, in the purple area of this same stain
(Figure 4a), several 2-3 $\mu \mathrm{m}$ spherical conidia with roughened walls were observed within the fibres (Figure $4 \mathrm{~b}$ ) under SEM. The species responsible for the production of those conidia remained unidentified since no other isolates were obtained.

Samples D2-C and D2-D were both collected from foxing spots, but only from sample D (Figure 4c), an isolate was retrieved: Eurotium rubrum (Table 1). Fungal spores compatible with Eurotium species were observed in D2-D stain (Figure 4d). This xerophilic fungus [28] has been previously identified on foxing stains and is able to produce brown colourants [37-38].

Document D3 exhibited mostly dark brown or black stains. Sample D3-A (Figure 5a) revealed Stachybotrys chartarum characteristic conidiophores and black conidia [27] (Figure 5b), in a well-developed black coloured colony. However, the obtained isolates did not match this species (Table 1). On sample D3-E, on the other hand, an isolate from S. chartarum was identified, which could result from crosscontamination, since D3-A and D3-E were closely located. S. chartarum, a known paper colonizer [39-40], is a melanin producer [41], hence the black colour of its colony. Being a producer of highly toxic mycotoxins [42], the identification of such a developed colony of $S$. chartarum on this document alerts to potential health hazards related to the handling of fungal contaminated objects.

The high frequency of Chaetomium murorum (= Botryotrichum murorum [43]) on document D3 is noteworthy, since this species is rarely identified on paper

Table 1. Sampled stains from Document 1 (D1), Document 2 (D2) and Document 3 (D3) with respective observed colour and L"a*b* coordinates, isolated fungal species, and correlation with fungal structures directly observed in the stains (-: negative correlation; +: possible correlation).

\begin{tabular}{|c|c|c|c|c|c|}
\hline Doc & Stain & Colour & Isolated fungi (similarity \%) & $\begin{array}{l}\text { Accession } \\
\text { number }\end{array}$ & $\begin{array}{l}\text { Correlation } \\
\text { observed/isolated }\end{array}$ \\
\hline \multirow[t]{10}{*}{ D1 } & A & Brownish grey & $\mathrm{N} / \mathrm{A}$ & $\mathrm{N} / \mathrm{A}$ & $\mathrm{N} / \mathrm{A}$ \\
\hline & \multirow[t]{2}{*}{$\mathrm{B}$} & \multirow[t]{2}{*}{ Dark grey } & Penicillium citrinum (99) & KT898637.1 & - \\
\hline & & & Chaetomium globosum (99) & EU128633.1 & - \\
\hline & $\mathrm{C}$ & Greyish Brown & $\mathrm{N} / \mathrm{A}$ & $\mathrm{N} / \mathrm{A}$ & $\mathrm{N} / \mathrm{A}$ \\
\hline & $\mathrm{D}$ & Orange & $\mathrm{N} / \mathrm{A}$ & $\mathrm{N} / \mathrm{A}$ & $\mathrm{N} / \mathrm{A}$ \\
\hline & E & Greyish brown & $\mathrm{N} / \mathrm{A}$ & $\mathrm{N} / \mathrm{A}$ & $\mathrm{N} / \mathrm{A}$ \\
\hline & $\mathrm{F}$ & Reddish brown & $\mathrm{N} / \mathrm{A}$ & $\mathrm{N} / \mathrm{A}$ & $\mathrm{N} / \mathrm{A}$ \\
\hline & G & Brown, black \& olive green spots & $\mathrm{N} / \mathrm{A}$ & $\mathrm{N} / \mathrm{A}$ & $\mathrm{N} / \mathrm{A}$ \\
\hline & \multirow[t]{2}{*}{$\mathrm{H}$} & \multirow[t]{2}{*}{ Dark brown spots } & Chaetomium globosum (99) & EU330625.2 & + \\
\hline & & & Chaetomium globosum (99) & $\mathrm{AB} 449671.1$ & + \\
\hline \multirow[t]{4}{*}{$\mathrm{D} 2$} & A & Purple with orange spots & Penicillium citrinum (99) & KP942904.1 & + \\
\hline & B & Brown/orange, grey spots & $\mathrm{N} / \mathrm{A}$ & $\mathrm{N} / \mathrm{A}$ & $\mathrm{N} / \mathrm{A}$ \\
\hline & C & Brownish orange & $\mathrm{N} / \mathrm{A}$ & $\mathrm{N} / \mathrm{A}$ & $\mathrm{N} / \mathrm{A}$ \\
\hline & $\mathrm{D}$ & Brownish orange & Eurotium rubrum (99) & U18357.1 & + \\
\hline
\end{tabular}


Fungal stains on paper: is what you see what you get?

Table 1 (continued)

\begin{tabular}{|c|c|c|c|c|c|}
\hline Doc & Stain & Colour & Isolated fungi (similarity \%) & $\begin{array}{l}\text { Accession } \\
\text { number }\end{array}$ & $\begin{array}{l}\text { Correlation } \\
\text { observed/isolated }\end{array}$ \\
\hline \multirow[t]{38}{*}{ D3 } & \multirow[t]{3}{*}{ A } & \multirow[t]{3}{*}{ Dark brown/black } & Chaetomium murorum (99) & JQ946413.1 & - \\
\hline & & & Chaetomium nigricolor (99) & $\mathrm{JF} 439467.1$ & - \\
\hline & & & Penicillium chrysogenum (100) & KT898599.1 & - \\
\hline & \multirow[t]{5}{*}{$\mathrm{B}$} & \multirow[t]{5}{*}{ Dark brown spots } & Chaetomium murorum (99) & JQ946413.1 & + \\
\hline & & & Penicillium chrysogenum (99) & $\mathrm{KT} 898599.2$ & - \\
\hline & & & Chaetomium murorum (100) & JQ946413.1 & + \\
\hline & & & Penicillium chrysogenum (99) & KT898599.1 & - \\
\hline & & & Chaetomium murorum (100) & JQ946413.1 & + \\
\hline & \multirow[t]{6}{*}{$\mathrm{C}$} & \multirow[t]{6}{*}{ Dark brown/black } & Chaetomium murorum (99) & JQ946413.1 & + \\
\hline & & & Chaetomium sp. (99) & $\mathrm{KC} 427007.1$ & + \\
\hline & & & Penicillium chrysogenum (99) & KT898599.1 & - \\
\hline & & & Penicillium chrysogenum (99) & KT898599.1 & - \\
\hline & & & Chaetomium murorum (100) & JQ946413.1 & + \\
\hline & & & Chaetomium murorum (100) & JQ946413.2 & + \\
\hline & \multirow[t]{4}{*}{$\mathrm{D}$} & \multirow[t]{4}{*}{ Dark brown } & Myxotrichum deflexum (99) & JQ781738.1 & + \\
\hline & & & Penicillium sp. (99) & JQ781832.1 & - \\
\hline & & & Myxotricum deflexum (99) & JQ781738.1 & + \\
\hline & & & Myxotricum deflexum (99) & JQ781738.1 & + \\
\hline & \multirow[t]{5}{*}{ E } & \multirow[t]{5}{*}{ Dark brown spots } & Chaetomium murorum (99) & JQ946413.1 & + \\
\hline & & & Penicillium chrysogenum (99) & KT898599.1 & - \\
\hline & & & Chaetomium murorum (99) & JQ946413.1 & + \\
\hline & & & Chaetomium murorum (99) & JQ946413.2 & + \\
\hline & & & Stachybotrys chartarum (99) & AFo81468.2 & - \\
\hline & $\mathrm{F}$ & Dark brown spots & Penicillium chrysogenum (99) & KT898599.1 & - \\
\hline & \multirow[t]{3}{*}{ G } & \multirow[t]{3}{*}{ Dark brown } & Penicillium chrysogenum (99) & LN809047.1 & + \\
\hline & & & Penicillium chrysogenum (99) & KT898599.3 & + \\
\hline & & & Penicillium chrysogenum (99) & LN809047.1 & + \\
\hline & \multirow[t]{4}{*}{$\mathrm{H}$} & \multirow[t]{4}{*}{ Dark brown } & Penicillium commune (99) & GQ458026.1 & + \\
\hline & & & Penicillium commune (99) & GQ458026.1 & + \\
\hline & & & Penicillium chrysogenum (99) & JQ781835.1 & + \\
\hline & & & Penicillium commune (99) & GQ458026.1 & + \\
\hline & I & Brown & $\mathrm{N} / \mathrm{A}$ & $\mathrm{N} / \mathrm{A}$ & $\mathrm{N} / \mathrm{A}$ \\
\hline & $\mathrm{J}$ & Brown & $\mathrm{N} / \mathrm{A}$ & N/A & $\mathrm{N} / \mathrm{A}$ \\
\hline & \multirow[t]{5}{*}{$\mathrm{K}$} & \multirow[t]{5}{*}{ Dark brown/black spots } & Chaetomium murorum (99) & JQ946413.2 & + \\
\hline & & & Chaetomium murorum (100) & JQ946413.2 & + \\
\hline & & & Chaetomium globosum (99) & EU301639.1 & + \\
\hline & & & Chaetomium murorum (99) & JQ946413.1 & + \\
\hline & & & Chaetomium globosum (99) & AB449671.1 & + \\
\hline
\end{tabular}

N/A: not applicable, no isolates were obtained. 
Samples with retrieved viable isolates (\%)

- Samples with possible match observation/identification (\%)

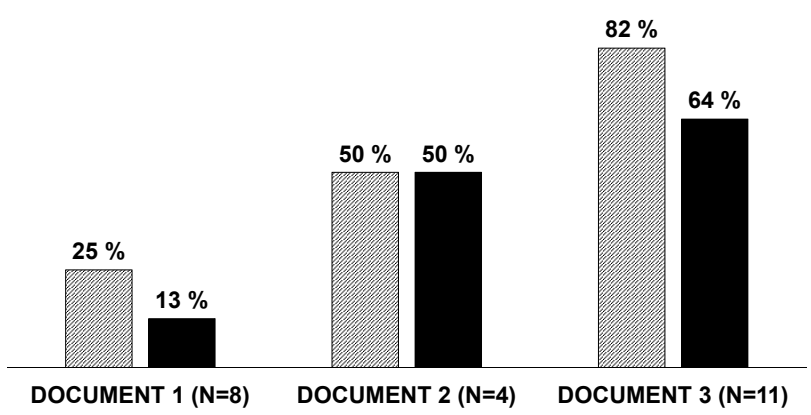

Figure 2. Percentage of samples yielding viable isolates, and samples with possible correspondence between observed fungal structures on the stains and identified isolates.
[11, 44], whilst C. globosum is much more frequent [3, 11, 29, 34]. Chaetomium species are well known for their ability to degrade cellulose [43]. C. globosum, the most common species of the more than 400 existing species of the Chaetomiaceae family in the indoor environment, has shown to be one of the important contributors to the development of symptoms of rhinitis, asthma and other health problems, being the most common human pathogen associated with nail infection [43]. Nevertheless, little is known about the other Chaetomium species and their potential hazard to humans and materials. Wang et al. [43] analysed the metabolic profile of several Chaetomium species and C. murorum has shown to produce a lower variety of toxic metabolites than C. globosum. Pietrzak et al. [45] analysed different fungal strains for their cellulolytic activity and C. murorum and C. globosum strains revealed no and low cellulolytic activity, respectively.

Myxotrichum deflexum, observed (Figure 5d) and identified (Table 1) on stain D3-D (Figure 5c), with its large dark brown balls of branching hyphae [46], has already been previously identified from paper collections [11, 47]. This species
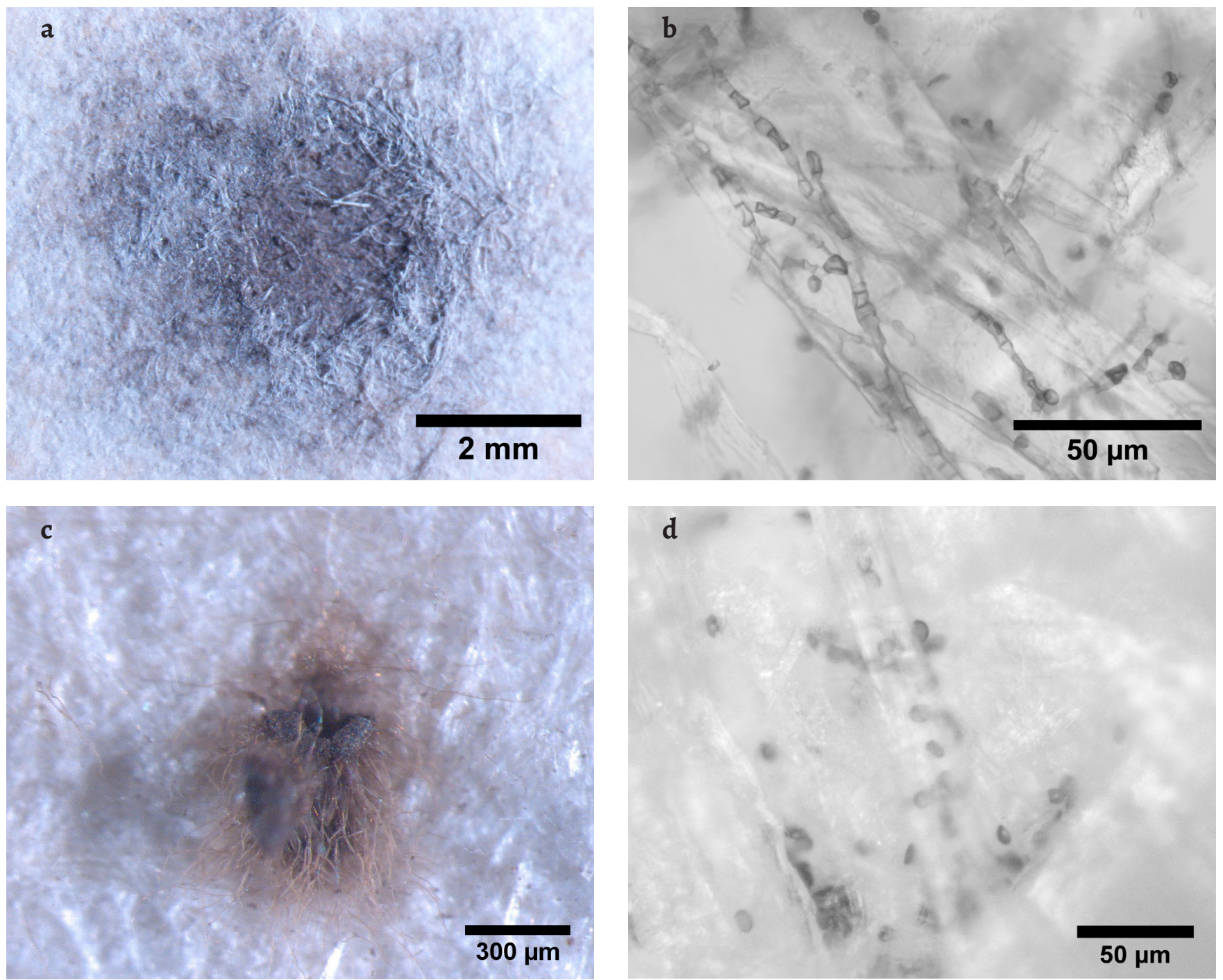

Figure 3. Stereo microscopy and OM images of stains and fungal structures observed on document D1: $a$ ) stain D1-B under the stereomicroscope; $b$ ) OM image of microbial cells observed on sample D1-B; $c$ ) stain D1-H under the stereomicroscope; $d$ ) OM image of ascospores observed within the paper fibres on sample Di-H. 

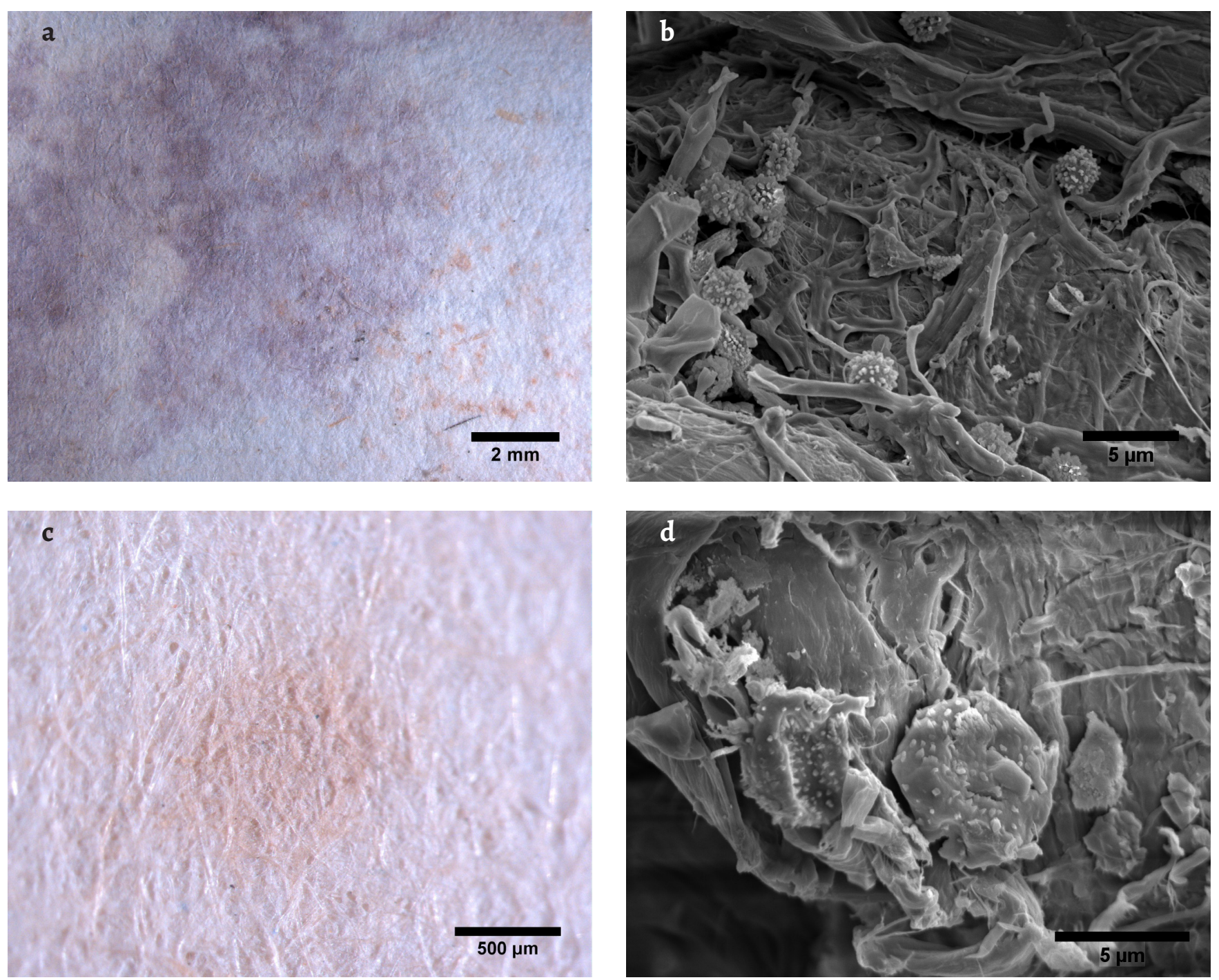

Figure 4. Stereo microscopy images of stains and SEM images of the respective fungal structures observed on document D2: a) stain D2-A under the stereo microscope; b) SEM image of conidia observed on the purple area of sample D2-A; c) stain D2-D under the stereo microscope; d) SEM image of spores observed on sample D2-D.

has also shown to possess paper colonizing ability due to its medium cellulolytic activity [45].

On both D3-G and D3-H samples, analogous agglomerates of spherical to ellipsoidal smooth walled conidia (2.5-3.7 $\mu \mathrm{m})$ were observed, with some conidial chains. These cells are consistent with the identified Penicillium species (P. chrysogenum and P. commune). Although no conidiophores were observed on the samples, which would help sustain the visual correlation with the obtained identification, getting multiple isolates of the same species in each sample supports a possible correlation. Fresh colonies of these Penicillium species have green hues but get darker with age [27], which could justify the dark brown colour observed on the stains.

On document $\mathrm{D} 3$, multiple isolates were retrieved from most stains. This can be the result of cross-contamination within the document: several fungal species were isolated from stains other than the ones where they were microscopically observed (Table 1). Besides, a stain caused by microorganisms can result from sequential or simultaneous colonization by different species.
According to Figure 2, the percentage of samples with a possible match between observed fungal structures and identified fungi varied from 13 to $64 \%$, within the three studied documents. The lack of sampling material on previously cleaned stains (D1) was a limiting factor. In addition to fungi, bacteria, which were not targeted on the present work, can also be responsible for stains on paper and can coexist with fungal species [16]. Since the identification of fungi was preceded by culture, only the species still viable and able to develop on the tested growth media could be identified, but, as described in the introduction section, all identification methods have limitations, which have to be assumed. New alternative methods are required, which can more directly relate a certain type of biodeterioration with its culprit.

Metabolite profiling can be a powerfull tool in the future, so that by analysing the chemical composition of a fungal stain we could point out to a possible perpetrator [12]. In the end, if the removal of a stain or neutralization of its noxious metabolites is the aim, knowing their chemical composition may be sufficient, although non-invasive methods with high 

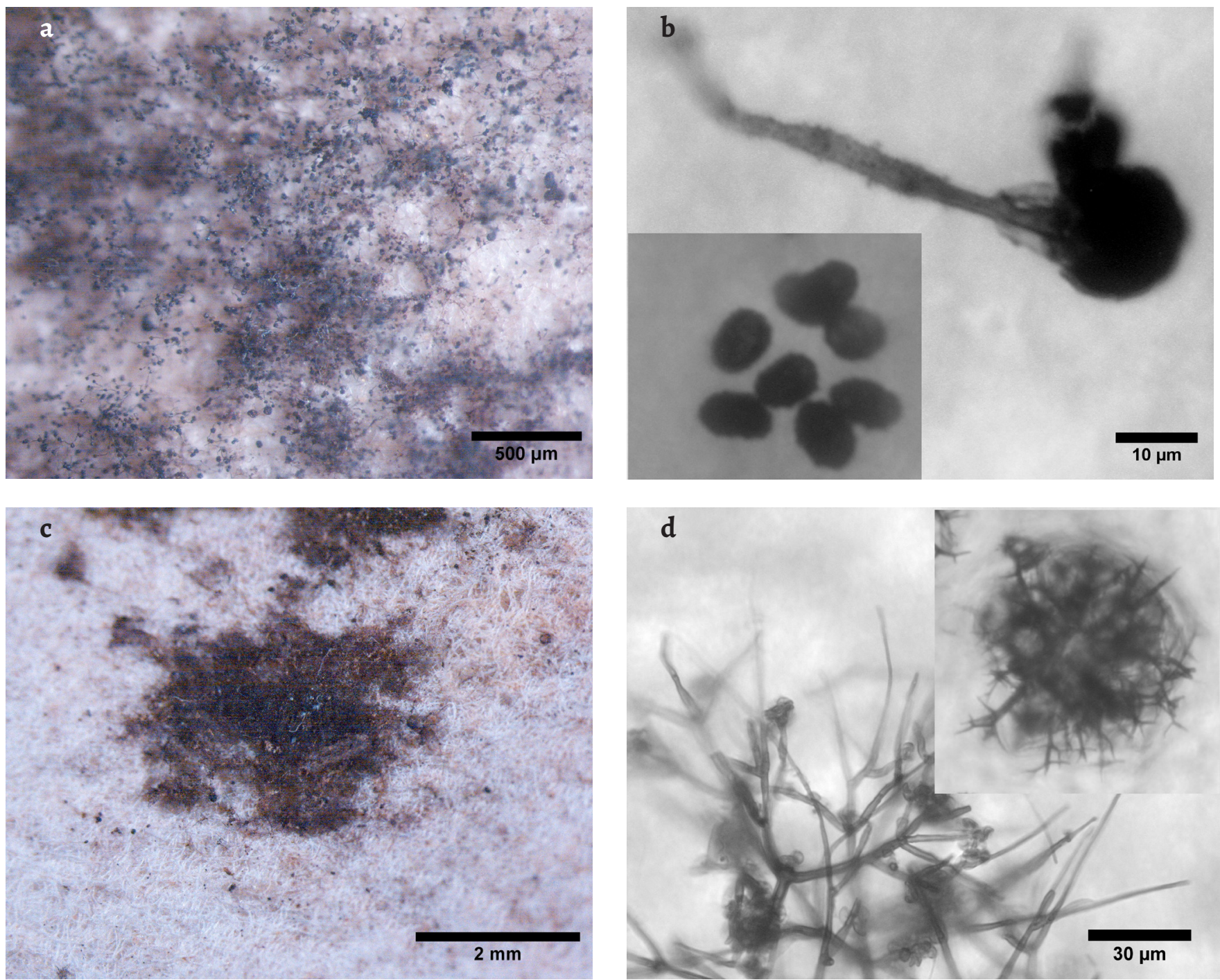

Figure 5. Stereo microscopy images of stains and OM images of the respective fungal structures observed on document D3: a) stain D3-A under the stereomicroscope; b) OM image of conidiophore and conidia (lower left corner detail) of Stachybotrys chartarum observed on sample D3-A; c) stain D3-D under the stereomicroscope; $d$ ) OM image of peridial hyphae and cleistothecium (upper right corner detail) of Myxotricum deflexum, observed on sample D3-D.

enough sensitivity to identify metabolites from cultural heritage objects are still needed.

The analysis presented here aimed to assign particular fungal species to specific types of biodeterioration, hence contributing to the development of proper and more focused conservation strategies to mitigate fungal biodeterioration of paper.

\section{Acknowledgements}

This work was funded with national funds by FCT - Fundação para a Ciência e Tecnologia, I. P., within the scope of CleanART research project (PTDC/EPHPAT/0224/2014), and VICARTE Research Unit (UID/EAT/00729/2013). Nuno Mesquita was supported by POCH - Programa Operacional Capital Humano (co-funding by the European Social Fund and national funding by MCTES), with a post-doc research grant (SFRH/BPD/112830/2015). The authors thank Sara Fragoso for offering the fungal stained print to this study.

\section{REFERENCES}

1. Sequeira, S. O.; Cabrita, E. J.; Macedo, M. F., 'Fungal biodeterioration of paper: how are paper and book conservators dealing with it? An International Survey', Restaurator 35(2) (2014) 181-199, https://doi.org/10.1515/rest-2014-0005.

2. Florian, M., Fungal Facts - Solving Fungal Problems in Heritage Collections, Archetype Publications, London (2002).

3. Rakotonirainy, M. S.; Heude, E.; Lavédrine, B., 'Isolation and attempts of biomolecular characterization of fungal strains associated to foxing on a 19th century book', Journal of Cultural Heritage 8(2) (2007) 126-133, https://doi.org/10.1016/j. culher.2007.01.003.

4. Allsopp, D.; Seal, K.; Gaylarde, C., Introduction to Biodeterioration, 2nd ed., Cambridge University Press, Cambridge (2004), https://doi.org/10.1017/CBO9780511617065.

5. Szczepanowska, H.; Lovett, C. M.; 'A study of the removal and prevention of fungal stains on paper', Journal of the American Institute for Conservation 31(2) (1992), 147-160, https://doi. org/10.2307/3179489. 
6. Karakasidou, K.; Nikolouli, K.; Amoutzias, G. D.; Pournou, A.; Manassis, C.; Tsiamis, G.; Mossialos, D., 'Microbial diversity in biodeteriorated Greek historical documents dating back to the 19th and 2oth century: a case study', MicrobiologyOpen (2018), https://doi.org/10.1002/mb03.596.

7. El Bergadi, F.; Laachari, F.; Elabed, S.; Mohammed, I. H.; Ibnsouda, S. K., 'Cellulolytic potential and filter paper activity of fungi isolated from ancients manuscripts from the Medina of Fez', Annals of Microbiology 64(2) (2014) 815-822, https://doi. org/10.1007/s13213-013-0718-6.

8. Borrego, S.; Lavin, P.; Perdomo, I.; Gómez de Saravia, S.; Guiamet, P., 'Determination of indoor air quality in archives and biodeterioration of the documentary Heritage', ISRN Microbiology 2012 (2012), 680598, https://doi. org/10.5402/2012/680598.

9. Coronado-Ruiz, C.; Avendaño, R.; Escudero-Leyva, E.; ConejoBarboza, G.; Chaverri, P.; Chavarría, M., 'Two new cellulolytic fungal species isolated from a 19th-century art collection', Scientific Reports 8(1) (2018) 1-9, https://doi.org/10.1038/ S41598-018-24934-7.

10. Polo, A.; Cappitelli, F.; Villa, F.; Pinzari, F., 'Biological invasion in the indoor environment: the spread of Eurotium halophilicum on library materials', International Biodeterioration \& Biodegradation 118 (2017) 34-44, https://doi.org/10.1016/j. ibiod.2016.12.010.

11. Kraková, L.; Šoltys, K.; Otlewska, A.; Pietrzak, K.; Purkrtová, S.; Savická, D.; Puškárová, A.; Bučková, M.; Szemes, T.; Budiš, J.; Demnerová, K.; Gutarowska, B.; Pangallo, D., 'Comparison of methods for identification of microbial communities in book collections: culture-dependent (sequencing and MALDI-TOF MS) and culture-independent (Illumina MiSeq)', International Biodeterioration \& Biodegradation 131 (2018) 51-59, https://doi.org/10.1016/j.ibiod.2017.02.015.

12. Sanmartín, P.; DeAraujo, A.; Vasanthakumar, A., 'Melding the old with the new: trends in methods used to identify, monitor, and control microorganisms on Cultural Heritage materials', Microbial Ecology 76(1) (2018) 64-80, https://doi.org/10.1007/ s00248-016-0770-4 .

13. Michaelsen, A.; Piñar, G.; Montanari, M.; Pinzari, F., 'Biodeterioration and restoration of a 16th-century book using a combination of conventional and molecular techniques: a case study', International Biodeterioration \& Biodegradation 63(2) (2009) 161-168, https://doi.org/10.1016/j.ibiod.2008.08.007.

14. Michaelsen, A.; Piñar, G.; Pinzari, F., 'Molecular and microscopical investigation of the microflora inhabiting a deteriorated Italian manuscript dated from the thirteenth century', Microbial Ecology 60(1) (2010) 69-80, https://doi.org/10.1007/ soo248-010-9667-9.

15. Piñar, G.; Sterflinger, K.; Pinzari, F., 'Unmasking the measleslike parchment discoloration: molecular and microanalytical approach', Environmental Microbiology 17(2) (2015) 427-443, https://doi.org/10.1111/1462-2920.12471.

16. Piñar, G.; Tafer, H.; Sterflinger, K.; Pinzari, F., 'Amid the possible causes of a very famous foxing: Molecular and microscopic insight into Leonardo da Vinci's self-portrait', Environmental Microbiology Reports 7(6) (2015) 849-859, https:// doi.org/10.1111/1758-2229.12313.
17. Schabereiter-Gurtner, C.; Piñar, G.; Lubitz, W.; Rölleke, S., 'Analysis of fungal communities on historical church window glass by denaturing gradient gel electrophoresis and phylogenetic 18S rDNA sequence analysis', Journal of Microbiological Methods 47(3) (2001) 345-354, https://doi.org/10.1016/ S0167-7012(01)00344-X.

18. Lupan, I.; Popescu, O. 'Metagenomics and future perspectives for biodeterioration and biodegradation studies', Annals of the Romanian Society for Cell Biology 17(2) (2012) 37-42.

19. Rosado, T.; Mirão, J.; Candeias, A.; Caldeira, A. T., 'Microbial communities analysis assessed by pyrosequencing - A new approach applied to conservation state studies of mural paintings', Analytical and Bioanalytical Chemistry 406(3) (2014) 887895, https://doi.org/10.1007/s00216-013-7516-7.

20. Li, Q.; Zhang, B.; He, Z.; Yang, X., 'Distribution and diversity of bacteria and fungi colonization in stone monuments analyzed by high-throughput sequencing', PLoS One 11(9) (2016) 1-17, https://doi.org/10.1371/journal.pone.0163287.

21. Chimienti, G.; Piredda, R.; Pepe, G.; van der Werf, I. D.; Sabbatini, L.; Crecchio, C.; Ricciuti, P.; D’Erchia, A.; Manzari, M. C.; Pesole G., 'Profile of microbial communities on carbonate stones of the medieval church of San Leonardo di Siponto (Italy) by Illumina-based deep sequencing', Applied Microbiology and Biotechnology 100(19) (2016) 8537-8548, https:// doi.org/10.1007/s00253-016-7656-8.

22. Szulc, J.; Otlewska, A.; Ruman, T.; Kubiak, K.; KarbowskaBerent, J.; Kozielec, T.; Gutarowska, B., 'Analysis of paper foxing by newly available omics techniques', International Biodeterioration \& Biodegradation 132 (2018) 157-165, https://doi. org/10.1016/j.ibiod.2018.03.005.

23. Micheluz, A.; Manente, S.; Tigini, V.; Prigione, V.; Pinzari, F.; Ravagnan, G.; Varese, G.C., 'The extreme environment of a library: xerophilic fungi inhabiting indoor niches', International Biodeterioration \& Biodegradation 99 (2015) 1-7. https://doi.org/10.1016/j.ibiod.2014.12.012.

24. Pinzari, F.; Montanari, M.; Michaelsen, A.; Piñar, G., 'Analytical protocols for the assessment of biological damage in historical documents', Coalition 19 (2010) 6-13.

25. Watanabe, T., Pictorial Atlas of Soil and Seed Fungi: Morphologies of Cultured Fungi and Key to Species, $2^{\text {nd }}$ ed., CRC Press, Boca Raton (2002), https://doi.org/10.1201/9781420040821.

26. Seifert, K.; Morgan-Jones, G.; Gams, W.; Kendrick, B., The Genera of Hyphomycetes, CBS-KNAW Fungal Biodiversity Centre, Utrecht (2011).

27. Samson, R. A.; Hoekstra, E. S.; Frisvad, J. C.; O. Filtenborg (eds.), Introduction to Food and Airborne Fungi, $6^{\text {th }} \mathrm{ed}$., Centraalbureau Voor Schimmelculture, Utrecht (2000).

28. Pitt, J. I.; Hocking, A. D., Fungi and Food Spoilage, $3^{\text {rd }}$ ed., Springer, New York (2009), https://doi. org/10.1007/978-0-387-92207-2.

29. Mesquita, N.; Portugal, A.; Videira S.; Rodriguez-Echeverria, S.; Bandeira, A. M. L.; Santos, M. J. A.; Freitas, H., 'Fungal diversity in ancient documents. A case study on the Archive of the University of Coimbra', International Biodeterioration \& Biodegradation 63 (2009) 626-629, https://doi.org/10.1016/j. ibiod.2009.03.010. 
30. Sharma, D.; Shukla, A. K.; 'Starch hydrolysis and alpha-amylase activity of Aspergillus and Chaetomium', Asian Journal of Biochemistry 3(5) (2008) 284-289, https://doi.org/10.1016/j. ibiod.2009.03.010.

31. Abdel-Azeem, A. M.; Gherbawy, Y. A.; Sabry, A. M., 'Enzyme profiles and genotyping of Chaetomium globosum isolates from various substrates', Plant Biosystems 150(3) (2016) 420428, https://doi.org/10.1080/11263504.2014.984791.

32. Houbraken, J.; Frisvad, J. C.; Samson, R. A., 'Taxonomy of Penicillium section Citrina', Studies in Mycology 70 (2011) 53-138, https://doi.org/10.3114/sim.2011.70.02.

33. da Silva, M.; Moraes, A. M. L.; Nishikawa, M. M.; Gatti, M. J. A.; de Alencar, M. A. V.; Brandao, L. E.; Nobrega, A., 'Inactivation of fungi from deteriorated paper materials by radiation', International Biodeterioration \& Biodegradation 57(3) (2006) 163-167, https://doi.org/10.1016/j.ibiod.2006.02.003.

34. Corte, A. M.; Ferroni, A.; Salvo, V. S., 'Isolation of fungal species from test samples and maps damaged by foxing, and correlation between these species and the environment', International Biodeterioration \& Biodegradation 51 (2003) 167-173, https://doi.org/10.1016/S0964-8305(02)00137-3.

35. Oetari, A.; Susetyo-Salim, T.; Sjamsuridzal, W.; Suherman, E. A.; Monica, M.; Wongso, R.; Fitri, R.; Nurlaili, D. G.; Ayu, D. C.; Teja, T. P., 'Occurrence of fungi on deteriorated old dluwang manuscripts from Indonesia', International Biodeterioration \& Biodegradation 114 (2016) 94-103, https://doi.org/10.1016/j. ibiod.2016.05.025.

36. Gopinath, S. C. B.; Anbu, P.; Hilda, A. 'Extracellular enzymatic activity profiles in fungi isolated from oil-rich environments', Mycoscience 46(2) 119-126, https://doi.org/10.1007/ S10267-004-0221-9.

37. Florian, M. L. E.; Manning, L., 'SEM analysis of irregular fungal fox spots in an 1854 book: population dynamics and species identification', International Biodeterioration \& Biodegradation 46 (2000) 205-220, https://doi.org/10.1016/ So964-8305(00)00062-7.

38. Karbowska-Berent, J.; Jarmiłko, J.; Czuczko, J., 'Fungi in fox spots of a drawing by Leon Wyczółkowski', Restaurator 35(2) (2014) 159-179, https://doi.org/10.1515/rest-2014-1000.

39. Das, M. K. L.; Prasad, J. S.; Ahmad, S. K., 'Endoglucanase production by paper-degrading mycoflora', Letters in Applied Microbiology 25(5) (1997) 313-315, https://doi. org/10.1046/j.1472-765X.1997.00217.X.

40. Ricelli, A.; Fabbri, A.A.; Fanelli,C.; Menicagli, R.; Samaritani, S.; Pini, D.; Rapaccini, S.M.; Salvadori, P., 'Fungal growth on samples of paper: Inhibition by new antifungals', Restaurator 20(2) (1999) 97-107, https://doi.org/10.1515/rest.1999.20.2.97.

41. De La Rosa, J.M.; Martin-Sanchez, P.M.; Sanchez-Cortes, S.; Hermosin, B.; Knicker, H.; Saiz-Jimenez, C., 'Structure of melanins from the fungi Ochroconis lascauxensis and Ochroconis anomala contaminating rock art in the Lascaux Cave', Scientific Reports 7 (2017) 13441, https://doi.org/10.1038/ S41598-017-13862-7.

42. Foladi, S.; Hedayati, M.T.; Shokohi, T.; Mayahi, S., 'Study on fungi in archives of offices, with a particular focus on Stachybotrys chartarum', Journal de Mycologie Medicale 23(4) (2013) 242-246, https://doi.org/10.1016/j.mycmed.2013.09.003.
43. Wang, X. W.; Houbraken, J.; Groenewald, J. Z.; Meijer, M.; Andersen, B.; Nielsen, K. F.; Crous, P. W.; Samson, R. A., 'Diversity and taxonomy of Chaetomium and chaetomiumlike fungi from indoor environments', Studies in Mycology 84 (2016) 145-224, https://doi.org/10.1016/j.simyco.2016.11.005.

44. Zyska, B., 'Fungi isolated from library materials: A review of the literature', International Biodeterioration 8 Biodegradation 40(1) (1997) 43-51, https://doi.org/10.1016/ S0964-8305(97)00061-9.

45. Pietrzak, K.; Otlewska, A.; Dybka, K.; Danielewicz, D.; Pangallo, D.; Demnerová, K.; Durovic, M.; Kraková; Scholtz, L. V.; Bucková, M.; Puskarová, A.; Kucerová, I.; Skrdlantová, M.; Drabková, K.; Surma-Slusarska, B.; Gutarowska, B., 'A modern approach to biodeterioration assessment and disinfection of historical book', in A Modern Approach to Biodeterioration Assessment and the Disinfection of Historical Book Collections, ed. G. Beata, Institute of Fermentation Technology and Microbiology - Lodz University of Technology, Lódz (2016) 81-123.

46. Campbell, C. K.; Johnson, E. M.; Warnock, D. W., Identification of Pathogenic Fungi, 2nd ed., Wiley-Blackwell, Chichester (2013), https://doi.org/10.1002/9781118520055.

47. Y Sato, Y.; Aoki, M.; Kigawa, R., 'Microbial deterioration of tsunami-affected paper-based objects: A case study', International Biodeterioration \& Biodegradation 88 (2014) 142149, https://doi.org/10.1016/j.ibiod.2013.12.007.

RECEIVED: 2018.3.7

REVISED: 2018.9.21

ACCEPTED: 2018.10 .12

ONLINE: 2018.11 .16

\section{(c) (1) () () $\Theta$}

This work is licensed under the Creative Commons.

Attribution-NonCommercial-NoDerivatives 4.0 International License. To view a copy of this license, visit:

http://creativecommons.org/licenses/by-nc-nd/4.o/deed.en. 